\title{
Evolution of microstructure and elevated-temperature properties during hot rolling and post-rolling annealing process in Al-Mg-Si 6082 alloys
}

\author{
$K . \mathrm{Liu}^{*}, C . \mathrm{Li}$, and $X .-G$. Chen \\ Department of Applied Science, University of Quebec at Chicoutimi, Saguenay, Quebec, Canada
}

\begin{abstract}
In the present work, the hot rolling at $400^{\circ} \mathrm{C}$ and post-rolling annealing at $500^{\circ} \mathrm{C}$ were applied on heat-treated Al-Mg-Si 6082 alloys with different $\mathrm{Mn}$ contents to study the evolution of microstructure and elevated-temperature properties. During the pre-heat treatment before rolling $\left(400^{\circ} \mathrm{C} / 2 \mathrm{~h}\right)$, a number of fine rod-like dispersoids formed in Mn-containing alloy while only high volume of larger $\mathrm{Mg}_{2} \mathrm{Si}$ particles was observed in the matrix of base alloy free of Mn. After hot rolling, the morphology of dispersoids was transferred from rod-like to spherical with finer size and increased number density while the dispersoids gradually coarsened during post-rolling annealing in Mn-containing alloy. The full recrystallization was completed after 1-2 $\mathrm{h}$ during annealing in the base alloy, while only partial recrystallization was observed in Mn-containing alloy. The micro-hardness at room temperature and the tensile yield strength at $300^{\circ} \mathrm{C}$ firstly increased from as-rolled condition to the initial stage of annealing $(1 \mathrm{~h})$ for both alloys, which was likely attributed to the dissolution of $\mathrm{Mg}_{2} \mathrm{Si}$ during the beginning of annealing. With further increasing annealing time (2-8 h), both the microhardness at room temperature and the elevated-temperature strengths of the base alloy remained similar, while they were slightly decreased in Mn-containing alloy owing to the partially recrystallization and coarsening of dispersoids. However, the elevated-temperature strengths were always higher in Mn-containing alloy than the base alloy while their differences between two alloys was reducing with prolonging the post-rolling annealing time. The tensile fracture surface was observed to be ductile for all the conditions of both alloys but the dimples in Mn-containing alloy were finer and much more uniformly distributed.
\end{abstract}

Keywords: Al-Mg-Si 6082 alloy; hot rolling ; post -rolling annealing; dispersoids, elevated-temperature properties

\section{Introduction}

In recent years, the increasing demands in the legislation about the exhaust emissions place higher requirement on the elevated-temperature $\left(250-350^{\circ} \mathrm{C}\right)$ performance of materials in automobile industrials, in which the Al-Mg-Si 6xxx aluminum alloys are widely used. As well-known, the mechanical properties of precipitationstrengthening 6xxx aluminum alloys will sharply drop at elevated temperature (e.g. $300^{\circ} \mathrm{C}$ ) under traditional heat treatment (solution treatment followed by artificial aging treatment) due to the fast-coarsening process of precipitates [1]. Therefore, how to improve the elevatedtemperature properties of $\mathrm{Al}-\mathrm{Mg}-\mathrm{Si}$ 6xxx aluminum alloys has been highlighted as one of the industrial key concerns. On the other hand, the introduce of thermalstable dispersoids during the proper heat treatment is proved to greatly improve the elevated-temperature properties in $3 \mathrm{xxx}$ and $4 \mathrm{xxx}$ alloys [2-5]. Though the evolution of dispersoids are also investigated in Al-MgSi 6xxx alloys [6-8], most of them focused on the influence of dispersoids on the recrystallization behaviors at room temperature and the role of dispersoids on the elevated-temperature mechanical properties of 6xxx aluminum alloys is rarely discussed.

Recently, our study has shown that the formation of Mn-containing dispersoids in Al-Mg-Si 6082 alloys is of greatly benefit for the enhancement of Yield Strength (YS) at $300^{\circ} \mathrm{C}$, which is increasing from $30 \mathrm{MPa}$ in alloy free of dispersoids to $70 \mathrm{MPa}$ in alloy containing dispersoids after treated at $400^{\circ} \mathrm{C} / 2 \mathrm{~h}$ [9]. Meanwhile, it is also proved that the formation the dispersoids can greatly inhibit the dynamic recrystallization during the hot rolling process $[9,10]$. However, limited work has been performed on the elevated-temperature properties as well as the evolution of dispersoids during the hot-rolling and the post-rolling annealing process in Al-Mg-Si 6xxx alloys, which is of significance to their industrial applications.

In the present work, the emphasis was put on the evolution of microstructure and YS at $300^{\circ} \mathrm{C}$ of $\mathrm{Al}-\mathrm{Mg}$ Si 6082 alloy containing various $\mathrm{Mn}$ during the hot rolling and post-rolling annealing process with the aid of optical and electron microscopy. Meanwhile, the fracture surface after tensile test at $300^{\circ} \mathrm{C}$ was analyzed to

\footnotetext{
* Corresponding author: kun.liu@uqac.ca
} 
discover the role of dispersoids on the failure mode at elevated temperature.

\section{Experimental}

In the present work, two Al-Mg-Si 6xxx alloys, which are free of Mn (Alloy A) and containing 0.5 wt.\% Mn (Alloy B), were cast (Table 1) and then heat treated at $400^{\circ} \mathrm{C} / 2 \mathrm{~h}$ according to our previous study $[9,11]$. The hot-rolling was performed at $400^{\circ} \mathrm{C}$ with the reduction of $90 \%$ (from $30 \mathrm{~mm}$ to $3 \mathrm{~mm}$ ). More details about the hotrolling process can be found in [9]. After rolling, the sample were further annealed at $500^{\circ} \mathrm{C}$ for $1,2,4$ and $8 \mathrm{~h}$, which was defined as post-rolling annealing process.

Table 1 Chemical composition of alloys in present work

\begin{tabular}{cccccc}
\hline & \multicolumn{5}{c}{ Element $($ wt. \%) } \\
\cline { 2 - 6 } Alloy \# & $\mathrm{Mg}$ & $\mathrm{Si}$ & $\mathrm{Mn}$ & $\mathrm{Fe}$ & $\mathrm{Al}$ \\
\hline $\mathrm{A}$ & 0.99 & 0.66 & $\mathbf{0}$ & 0.26 & Bal. \\
B & 1.07 & 0.67 & $\mathbf{0 . 5 2}$ & 0.27 & Bal. \\
\hline
\end{tabular}

The YS at $300^{\circ} \mathrm{C}$ under various conditions were measured from the tensile tests using Gleeble thermomechanical testing unit and the average value of 3 samples was calculated. The heating rate was controlled at $2^{\circ} \mathrm{C} / \mathrm{S}$ with a holding time of $3 \mathrm{~min}$ at target temperature and the strain rate was set as $0.001 \mathrm{~S}^{-1}$. The Vickers microhardness was measured at room temperature with a load of $10 \mathrm{~g}$ and a dwelling time of $20 \mathrm{~s}$. The indentations were assured on the interdendrite cell to evaluate the effect of precipitation/dispersoids on the properties and the average value was calculated from 15 measurements for each condition.

The evolution of microstructure during the rolling and annealing processes, such as the precipitation of $\mathrm{Mg}_{2} \mathrm{Si}$ and dispersoids, were characterized by Optical microscopy (OM), Scanning electron microscopy (SEM) and Transmission electron microscopy (TEM) while the fracture surface after tensile test was observed with SEM. Samples were etched with $0.5 \% \mathrm{HF}$ for $30 \mathrm{~s}$ to clearer display the large $\mathrm{Mg}_{2} \mathrm{Si}$ precipitates and dispersoids. The grain structure during rolling and annealing process was mapped and analyzed by Electron Back-Scatter Diffraction (EBSD) with a step size of $2 \mu \mathrm{m}$.

\section{Results and Discussion}

\subsection{Microstructure before and after rolling}

According to our previous study $[9,11]$, it is proved that the dispersoids have been fully precipitated to the stable condition after $400^{\circ} \mathrm{C} / 2 \mathrm{~h}$. Therefore, Fig. 1 shows the microstructure of experimental alloys after $400^{\circ} \mathrm{C} / 2 \mathrm{~h}$, which was defined as the pre-heat treatment before rolling. As shown in Fig. 1a, high volume of large $\mathrm{Mg}_{2} \mathrm{Si}$ particles have precipitated in the matrix besides the $\mathrm{Al}-\mathrm{Fe}-\mathrm{Si}$ intermetallics in Alloy A free of $\mathrm{Mn}$ (base alloy), which can be due to the relative low heat treatment temperature $\left(400^{\circ} \mathrm{C}\right)$.
However, the volume of $\mathrm{Mg}_{2} \mathrm{Si}$ precipitates in the matrix was greatly reduced in Alloy B (Fig.1 b) and they were dominantly located at the dispersoids free zone (DFZ, more details about DFZ can be found in [9]) while some smaller $\mathrm{Mg}_{2} \mathrm{Si}$ were occasionally observed in the interdendrite cell. On the other hand, high volume of fine dispersoids in dispersoids zone (DZ) was observed in Alloy B. As shown in Fig. 1c, high quantity dispersoids were precipitated with the morphology of cubic and rods, which were reported to be $\alpha-\mathrm{Al}(\mathrm{MnFe}) \mathrm{Si}$ dispersoids [9]. The dispersoids was reported to nucleate on the preformed $\mathrm{Mg}_{2} \mathrm{Si}$ and then decrease the volume of $\mathrm{Mg}_{2} \mathrm{Si}$ during the heat treatment $[6,12]$, explaining the less $\mathrm{Mg}_{2} \mathrm{Si}$ in the interdendrite cell in Alloy B. However, little dispersoids precipitated at the DFZ due to the lower super saturated solution level of Mn [2], therefore, some lager $\mathrm{Mg}_{2} \mathrm{Si}$ can still be observed in DFZ (Fig. 1b).

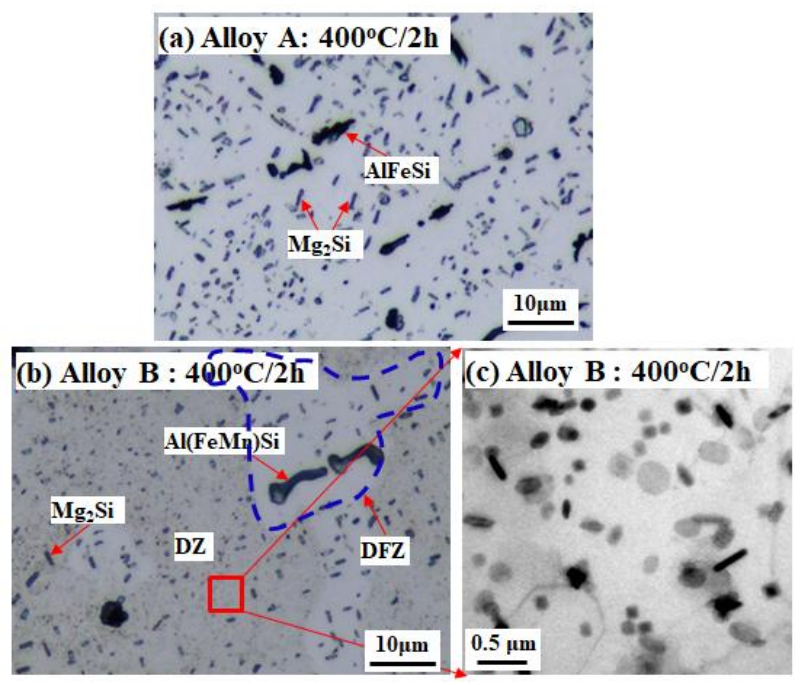

Fig. 1. Microstructure of experimental alloys after $400^{\circ} \mathrm{C} / 2 \mathrm{~h}$ (after etched): (a) Alloy A and (b, c) Alloy B

After pre-heat treatment $\left(400^{\circ} \mathrm{C} / 2 \mathrm{~h}\right)$, the experimental alloys were hot-rolled at $400^{\circ} \mathrm{C}$ and the as-rolled microstructure was illustrated in Fig. 2. For Alloy A (Fig. 2a-2b), the Al-Fe-Si intermetallics were fragmented to smaller particles while high volume of $\mathrm{Mg}_{2} \mathrm{Si}$ can still be observed (Fig. 2b). As shown in Fig. 1a, the size of $\mathrm{Mg}_{2} \mathrm{Si}$ before rolling was so bigger that they were hardly to be dissolved into matrix during the rolling. However, it seems they were also fragmented to smaller size due to the high deformation during the rolling.

Similar to Alloy A, the Al-Fe-Si intermetallics were also fragmentated in Alloy B (Fig. 2c). However, much less $\mathrm{Mg}_{2} \mathrm{Si}$ can be observed while the dispersoids were still present in the matrix (Fig. 2d). As shown in Fig. 1b, though lower volume of $\mathrm{Mg}_{2} \mathrm{Si}$ were remaining in Alloy B after $400^{\circ} \mathrm{C} / 2 \mathrm{~h}$, their size was much smaller than that in Alloy A (Fig. 1a), leading to it easier for them to dissolve into matrix during the hot-rolling process. Meanwhile, it is interesting to be noted that the dispersoids after hot-rolling (Fig. 2e) is greatly different with that before rolling (Fig. 1c) that the morphology of dispersoids were much more spherical and their size was finer with higher number density after rolling (Fig. 2e). The reason of this evolution of dispersoids is still under 
investigation but the favourable conditions promoting precipitation induced by the dislocations or sub-grain boundaries formed during the hot rolling was a plausible cause [13].
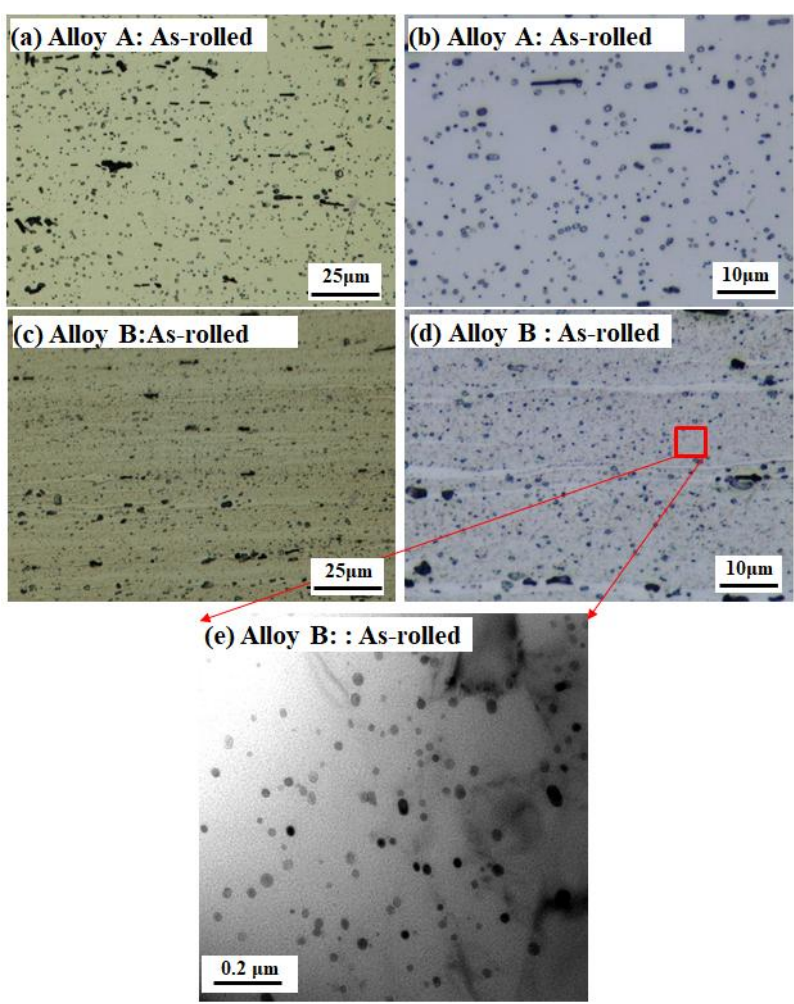

Fig. 2. As-rolled microstructure of experimental alloys (after etching): (a-b) Alloy A and (c-d) Alloy B

Fig. 3 displays the as-rolled grain structure of experimental alloys from the EBSD mapping analysis. It can be found that the as-rolled grain in Alloy A is almost equiaxed while some elongated grains in the rolling direction can still be observed (Fig. 3a), indicating that the partial or close-fully recrystallization during the rolling process in Alloy A occurred. This was also confirmed by the scattered and weaker texture from the $\{111\}$ pole figure in Fig. 3a. As shown in Fig. 1a and 2b, only coarse $\mathrm{Mg}_{2} \mathrm{Si}$ particles and fragmented Al-Fe-Si particles present in Alloy $\mathrm{A}$, which have limited retarding effect on recrystallization during the hot-rolling process. Therefore, the recrystallized microstructure (equiaxed grains) was mostly observed in as-rolled condition of Alloy A.

However, the as-rolled microstructure was different in Alloy B (Fig. 3b) that the lamellar structure was dominate with deformed bands and highly elongated grains. Meanwhile, the $\{111\}$ pole figure also showed the strong rolling texture, which was similar to the Brass and $\mathrm{S}$ texture [14]. This can be attributed to the precipitation of high volume of dispersoids in Alloy B, which have the strong pinning effect on the recrystallization during the hot-rolling $[2,9]$.
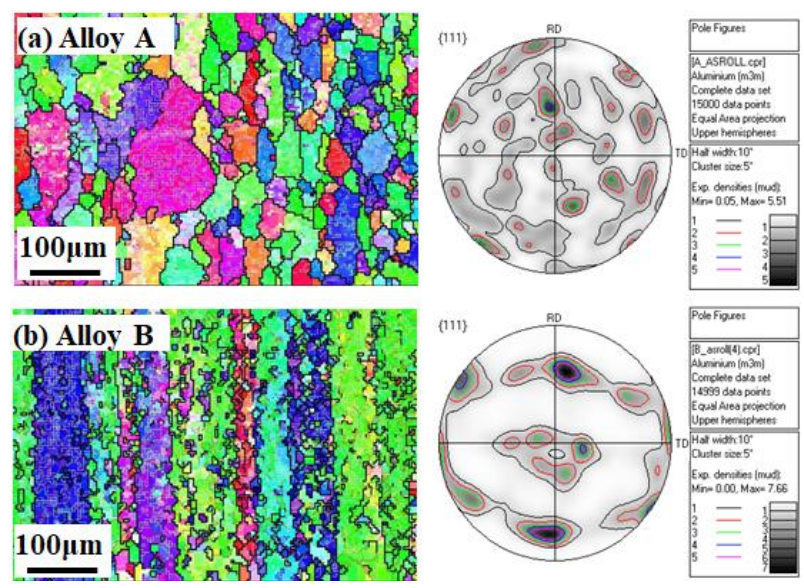

Fig. 3. As-rolled grain structure and the $\{111\}$ pole figure from EBSD mapping of experimental alloys

\subsection{Microstructure during the post-rolling annealing process}

As shown in Figs. 2 and 3, different microstructure and grain structure was observed in Alloy A and Alloy B, which will also affect the microstructures during the post-rolling annealing process. Fig. 4 shows the annealing microstructure of experimental alloys after $1 \mathrm{~h}$ and $8 \mathrm{~h}$ at $500^{\circ} \mathrm{C}$. For Alloy A, it can be seen that only the $\mathrm{Al}-\mathrm{Fe}-\mathrm{Si}$ intermetallics remains in the alloy while almost all the $\mathrm{Mg}_{2} \mathrm{Si}$ particles present in Fig. $2 \mathrm{~b}$ has dissolved into matrix after $1 \mathrm{~h}$ annealed at $500^{\circ} \mathrm{C}$, as shown in Fig. 4a. The microstructure keeps similar even after $500^{\circ} \mathrm{C} / 8 \mathrm{~h}$ (Fig. $4 \mathrm{~b}$ ) that the matrix is clean with only fragmented Al-Fe-Si intermetallics.
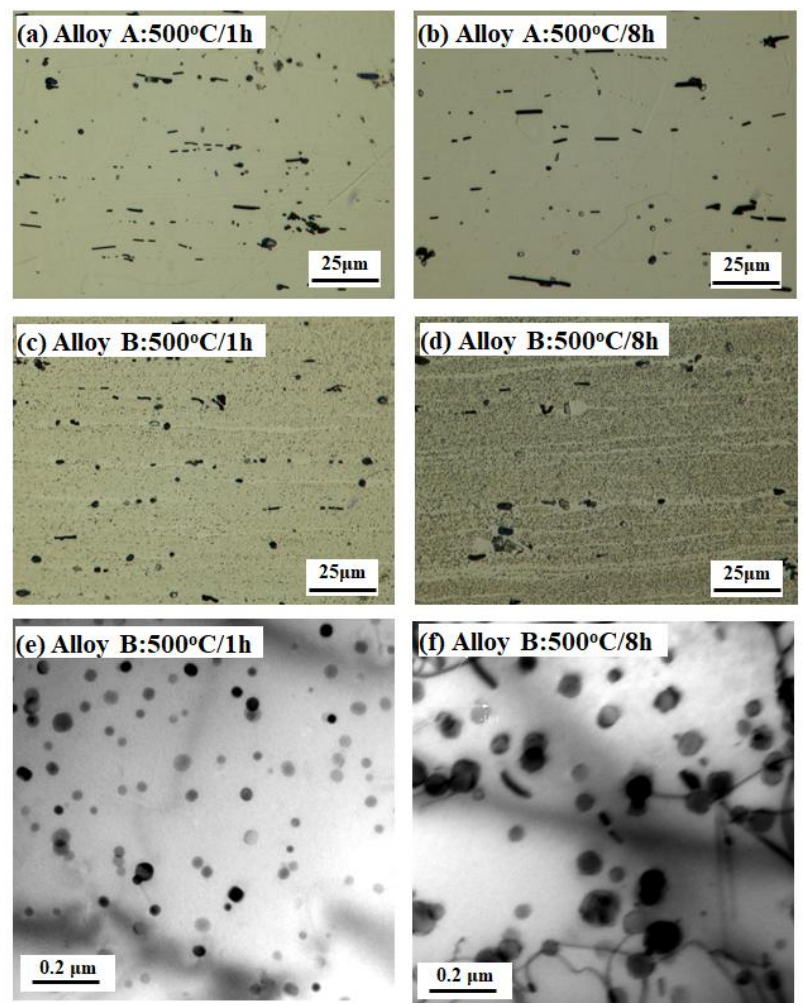

Fig. 4. Annealed microstructure of experimental alloys after $1 \mathrm{~h}$ and $8 \mathrm{~h}$ at $500^{\circ} \mathrm{C}$ 
Compared with the as-rolled microstructure of Alloy $\mathrm{B}$ in Fig. $2 \mathrm{~d}$, all the $\mathrm{Mg}_{2} \mathrm{Si}$ in Alloy B after $500^{\circ} \mathrm{C} / 1 \mathrm{~h}$ has also been fully dissolved into matrix (Fig. 4c), which is similar to Alloy A. This can be attributed to the higher annealing temperature $\left(500^{\circ} \mathrm{C}\right)$. Meanwhile, it is observed that the dispersoids coarsened during the annealing process. As shown in Fig. 4d of annealed after $500^{\circ} \mathrm{C} / 8 \mathrm{~h}$, the color of dispersoids zone was much darker, which was further confirmed by the TEM observation in Fig. 4e and 4f. Compared with the dispersoids in asrolled condition (Fig. 2e), the dispersoids was gradually coarsened after $500^{\circ} \mathrm{C} / 1 \mathrm{~h}$ (Fig. 4e) and they are even much bigger after $500^{\circ} \mathrm{C} / 8 \mathrm{~h}$ (Fig. $4 \mathrm{f}$ ). The coarsening process of dispersoids during the annealing process can be related to the formed and stored dislocations or subgrains during the hot-rolling, which was favorite for the nucleation and coarsening of dispersoids $[12,13]$.

Fig.5 shows the evolution of grain structure of experimental alloys during the post-rolling annealing process, in which the differences can be observed between two alloys. As shown in Fig. 5a-5d, the equiaxed grains were always present in Alloy A free of $\mathrm{Mn}$ and the fully recrystallization was assumed to complete only after $500^{\circ} \mathrm{C} / 2 \mathrm{~h}$ (Fig. 5b), representing as the uniformed distributed equiaxed grains and they were gradually growing with the increase of annealing time, as shown in Fig. 5c-5d.
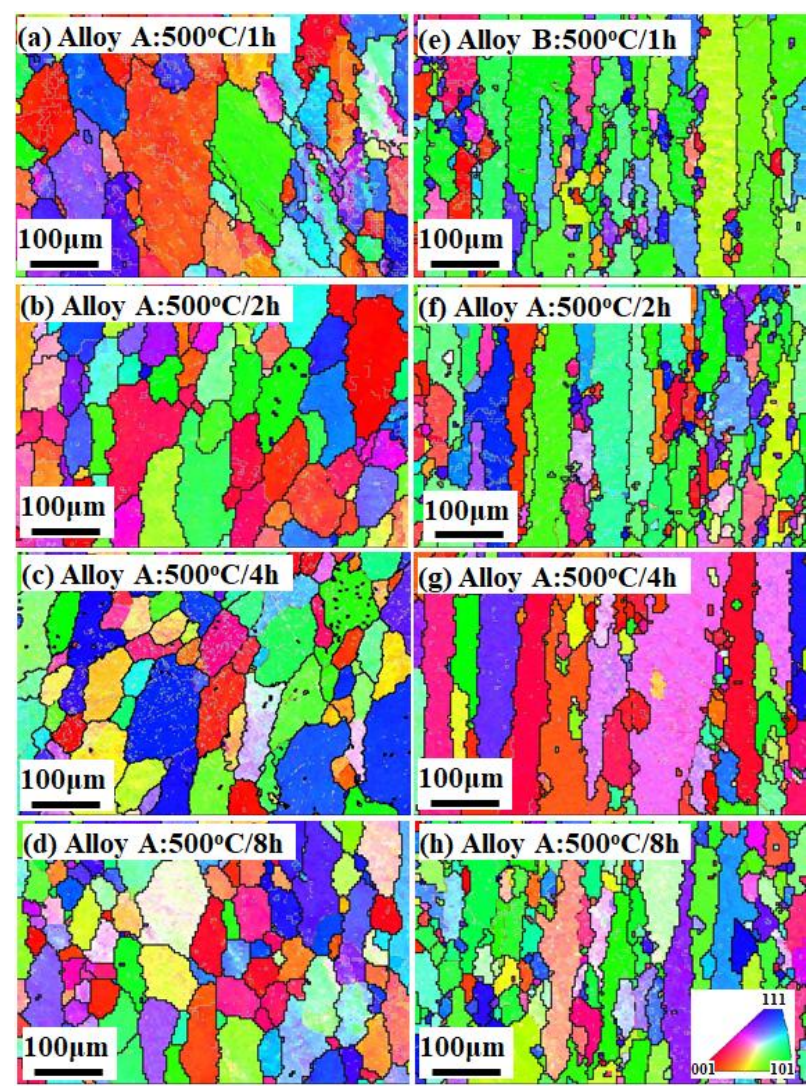

Fig. 5. Evolution of grain structure of experimental alloys during the post-rolling annealing process: (a-d) Alloy and (e-h) Alloy B

However, different grain structures from Alloy A were observed in Alloy B containing dispersoids due to the addition of Mn. As shown in Fig. 5e-5g, the similar lamellar structure to the as-rolled condition (Fig. 3b) with elongated grains and deformation bands was dominate until to $500^{\circ} \mathrm{C} / 4 \mathrm{~h}$ (Fig. $5 \mathrm{~g}$ ) thought some fine recrystallized grains can be observed after $500^{\circ} \mathrm{C} / 2 \mathrm{~h}$ (Fig. 5f) and $500^{\circ} \mathrm{C} / 4 \mathrm{~h}$ (Fig. 5g). With prolonged annealing time $\left(500^{\circ} \mathrm{C} / 8 \mathrm{~h}\right.$ in Fig. $\left.5 \mathrm{~h}\right)$, more recrystallized grains were observed between the elongated grains, indicating the partial discontinuous recrystallization occurred [15]. However, the volume fraction of recrystallization was still lower, even after $500^{\circ} \mathrm{C} / 8 \mathrm{~h}$ $(<20$ vol.\%), and the elongated recovery grains were still dominant structure in Alloy B during the postrolling annealing process, which is greatly different with the fully recrystallized structure in Alloy A.

The different recrystallization behavior between two experimental alloys can be explained by the formation of dispersoids in Alloy $\mathrm{B}$ since $\mathrm{Mg}_{2} \mathrm{Si}$ were already dissolved into matrix in both alloys (Fig. 4). In Alloy A, no precipitation or dispersoids were present (Fig. 4a-b) in the matrix and then the recrystallization was easier to occur and even it has fully completed after $500^{\circ} \mathrm{C} / 2 \mathrm{~h}$. However, there were high density of fine dispersoids formed after pre-heat treatment (Fig. 1c) and they were even much finer with increased number density after rolling (Fig. 2e), which were reported to strongly inhibit the recrystallization through increasing the Zener drag force due to its finer size and higher number density [4, 16]. Therefore, the recrystallization in Alloy B was greatly retarded (Fig. 4e) while it was gradually happened after $500^{\circ} \mathrm{C} / 8 \mathrm{~h}$ due to the reduced Zener drag force from coarsened of dispersoids (Fig. 4f).

\subsection{Evolution of elevated-temperature properties during the post-rolling annealing process}

As shown in Figs. 4 and 5, it can be observed that the grain structure as well as the formation of precipitates and dispersoids were greatly different between Alloy A and Alloy $\mathrm{B}$ after rolling and post-rolling annulling process, which would also lead to the various mechanical properties. In the present work, the tensile tests at $300^{\circ} \mathrm{C}$ were performed. According to the evolution of microstructure shown in Figs. 4 and 5, the tensile train-stress curves under conditions of as-rolled, $500^{\circ} \mathrm{C} / 1 \mathrm{~h}$ and $500^{\circ} \mathrm{C} / 8 \mathrm{~h}$ were shown in Fig. 6. It can be found the total strain at failure under all these conditions of experimental alloys was in the range 0.3-0.4 (except Alloy A after $500^{\circ} \mathrm{C} / 1 \mathrm{~h}$ ), indicating the excellent ductility of experimental $6 \mathrm{xxx}$ aluminum alloys at $300^{\circ} \mathrm{C}$. Meanwhile, it was also observed that the tensile stress in Alloy B was always higher than that in Alloy A during the tests in all the conditions. As shown in Fig. 6a, the ultimate tensile strength (UTS) at $300^{\circ} \mathrm{C}$ of Alloy B was measured to be $78 \mathrm{MPa}$, which was the almost doubled of that in Alloy A (42 MPa). During the post-rolling annealing process, it seemed that the extent of differences on the UTS was decreasing with increasing annealing time. For instance, the differences of UTS between two alloys decreased to $13 \mathrm{MPa}$ after $500^{\circ} \mathrm{C} / 1 \mathrm{~h}$ (Fig. 6b) and further to $7 \mathrm{MPa}$ after $500^{\circ} \mathrm{C} / 8 \mathrm{~h}$ (Fig. 6c). 
Furthermore, it was more interesting to notice that the total tensile strain of Alloy B was still higher than Alloy A, especially at as-rolled condition (Fig. 6a) and the beginning of annealing process (Fig. 6b) while the strength of Alloy B was also higher than Alloy A, which was similar to the results in Al-Si 356 alloys that Mocontaining dispersoids improved both the strength and ductility [17].
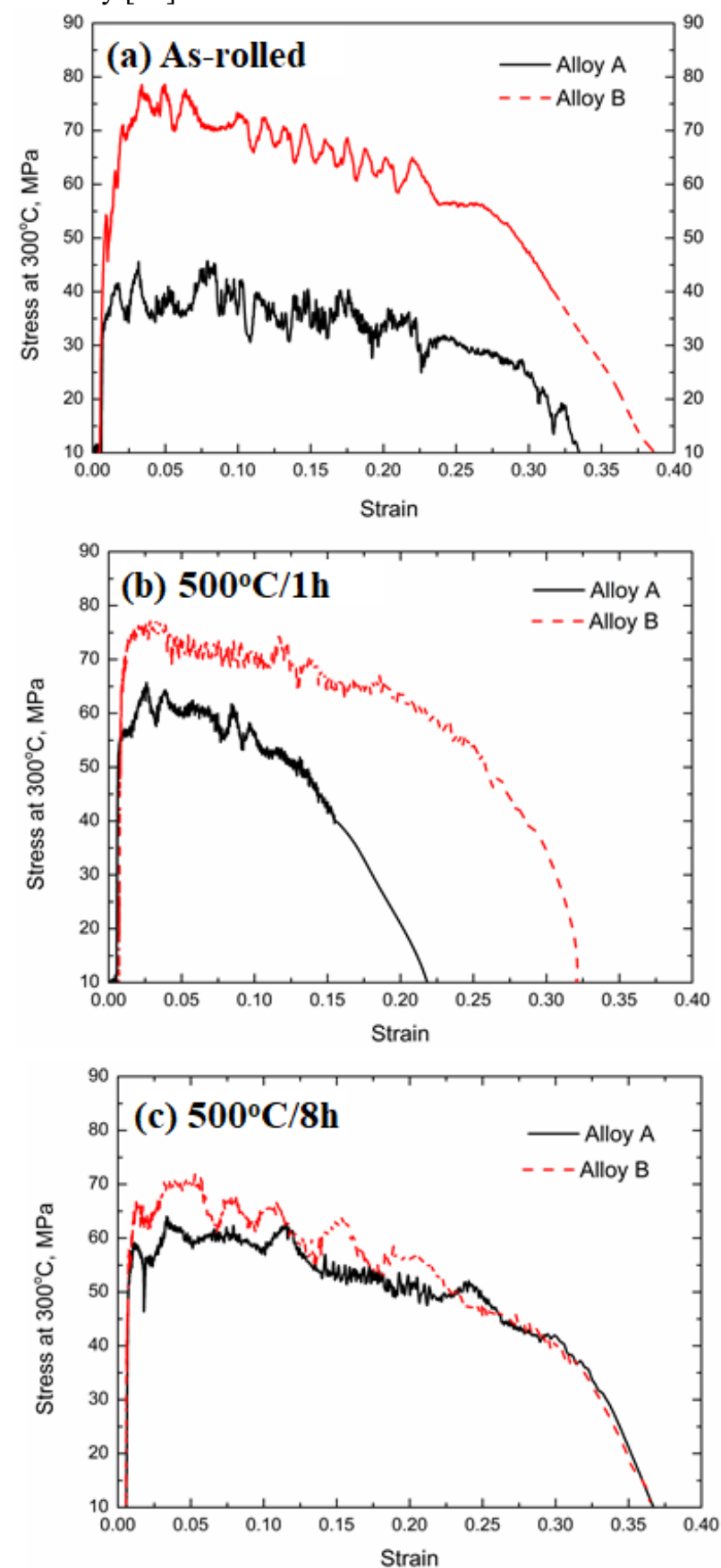

Fig. 6. Tensile strain-stress curves at $300^{\circ} \mathrm{C}$ of experimental alloys at: (a) as-rolled; (b) $500^{\circ} \mathrm{C} / 1 \mathrm{~h}$ and (c) $500^{\circ} \mathrm{C} / 8 \mathrm{~h}$

In order to fully evaluate the evolution of mechanical properties of experimental alloys, Fig. 7 displayed the evolution of microhardness at room temperature (RT) as well as the tensile YS at $300^{\circ} \mathrm{C}$ experimental alloys during the rolling as well as the post-rolling annealing process. As shown in Fig. 7, the evolution of microhardness at room temperature and the tensile YS at $300^{\circ} \mathrm{C}$ was generally similar for both experimental alloys that it was firstly increased from as-rolled condition to $500^{\circ} \mathrm{C} / 1 \mathrm{~h}$ and then stabilized (Alloy A) or gradually decreased (Alloy B) with prolonging of the post-rolling annealing time, which was agreed with the tendency shown in Fig. 6. For instance, the microhardness of Alloy A increased from $56 \mathrm{HV}$ at as-rolled condition to $77 \mathrm{HV}$ after $500^{\circ} \mathrm{C} / 1 \mathrm{~h}$ and then reduced to $74-75$ after $500^{\circ} \mathrm{C} / 8 \mathrm{~h}$ while the YS at $300^{\circ} \mathrm{C}$ was initially increased from $35 \mathrm{MPa}$ at as-rolled condition to $56 \mathrm{MPa}$ after $500^{\circ} \mathrm{C} / 1 \mathrm{~h}$ and then stabilized at $56-57 \mathrm{MPa}$ until to $500^{\circ} \mathrm{C} / 8 \mathrm{~h}$. However, it was observed that both the microhardness at RT and the YS at $300^{\circ} \mathrm{C}$ in Alloy B were always higher than that in Alloy A, especially at asrolled condition. As shown in Fig. 7, the as-rolled microhardness at RT and YS at $300^{\circ} \mathrm{C}$ of Alloy B were $80 \mathrm{HV}$ and $54 \mathrm{MPa}$, respectively, which were much higher than that of Alloy A (56 HV and $35 \mathrm{MPa}$ ). However, the differences of mechanical properties between two experimental alloys were reducing with prolonging the annealing time during the post-rolling annealing process. For instance, the differences of YS at $300^{\circ} \mathrm{C}$ between Alloy A and Alloy B was decreasing from $19 \mathrm{MPa}$ at as-rolled condition to $11 \mathrm{MPa}$ after $500^{\circ} \mathrm{C} / 1 \mathrm{~h}$ and $7 \mathrm{MPa}$ after $500^{\circ} \mathrm{C} / 2-4 \mathrm{~h}$ and then $5 \mathrm{MPa}$ after $500^{\circ} \mathrm{C} / 8 \mathrm{~h}$.
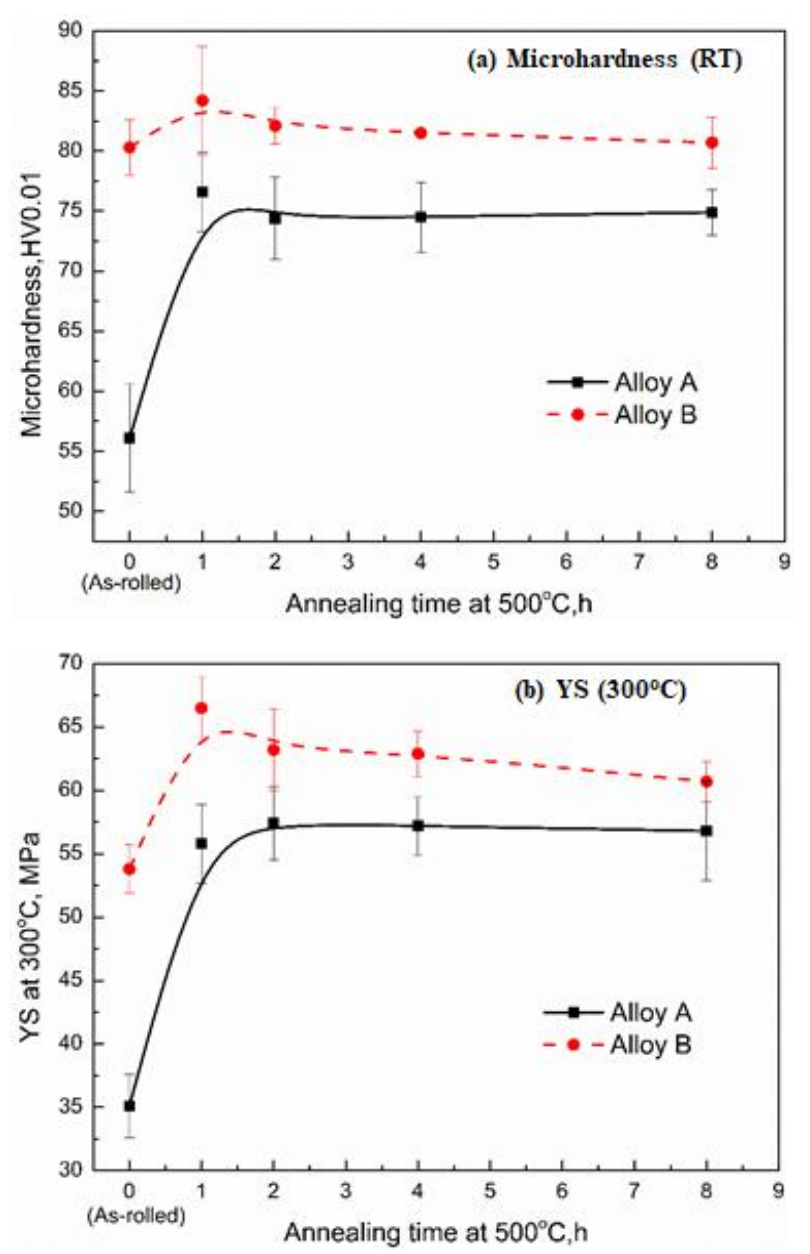

Fig. 7. Evolution of mechanical properties of experimentally alloys during the post-rolling annealing process: (a) Microhardness at RT and (b) tensile YS at $300^{\circ} \mathrm{C}$ 
The evolution of mechanical properties was greatly related to the change of microstructures during the postrolling annealing process. As shown in Fig. 2 and Fig. 4, high volume of $\mathrm{Mg}_{2} \mathrm{Si}$ was observed to fully dissolve into the matrix after $500^{\circ} \mathrm{C} / 1 \mathrm{~h}$, which can be the likely reason for the initial increase of microhardness and YS from as-rolled condition to $500^{\circ} \mathrm{C} / 1 \mathrm{~h}$. However, it can be found that much higher volume of $\mathrm{Mg}_{2} \mathrm{Si}$ in Alloy $\mathrm{A}$ were dissolved than Alloy B after $500^{\circ} \mathrm{C} / 1 \mathrm{~h}$, explaining the higher increasing degree of mechanical properties of Alloy $A$ at this stage. After $500^{\circ} \mathrm{C} / 1-2 \mathrm{~h}$, the fully recrystallization was observed in Alloy A followed by a minor growth of grain, leading to the stabilization of microhardness at RT and $\mathrm{YS}$ at $300^{\circ} \mathrm{C}$ while the partially recrystallization and coarsening of dispersoids was occurred in Alloy $\mathrm{B}$ with increasing post-rolling annealing time, resulting in its minor reduced mechanical properties during the annealing process. However, the contribution of dispersoids on the mechanical properties can be clearly demonstrated by the difference between both the microhardness at RT and YS at $300^{\circ} \mathrm{C}$. For instance, the difference of YS at $300^{\circ} \mathrm{C}$ at as-rolled condition between Alloy B and Alloy A was $19 \mathrm{MPa}$ due to the high quantity of finer dispersoids as well as the higher $\mathrm{Mg}$ and $\mathrm{Si}$ solid solution strengthening induced by the formation of dispersoids (Figs. 2e and 4e) and it was still $5 \mathrm{MPa}$ after $500^{\circ} \mathrm{C} / 8 \mathrm{~h}$ though the dispersoids has greatly coarsened (Fig. 4f). It should not be underestimated this " $5 \mathrm{MPa}$ " different on the YS at $300^{\circ} \mathrm{C}$ since every "1 MPa" counts for the mechanical properties at elevated temperature. For instance, it was reported that the creep resistance of materials could be improved one order with increasing of $3 \mathrm{MPa}$ on the threshold stress at $300^{\circ} \mathrm{C}[2,18]$.

The fracture surface after tensile test at $300^{\circ} \mathrm{C}$ of experimental alloys was analyzed using SEM and shown in Fig. 8.
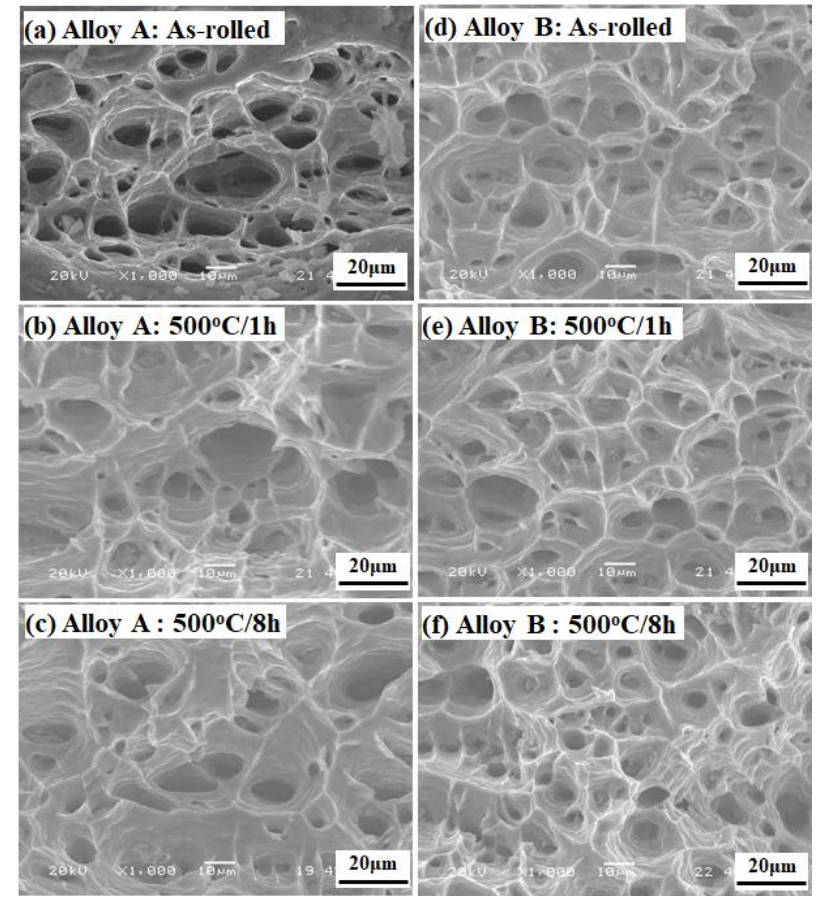

Fig. 8. Fracture surface of experimental alloys after various conditions
It can be found that the failure mode of both experimental alloys at all conditions was ductile due to the high tensile temperature $\left(300^{\circ} \mathrm{C}\right)$, representing by the formation of dimples at the fracture surface. However, the dimples in Alloy B were smaller and more uniform than that in Alloy A, which can be attributed to the homogenous deformation due to the presence of dispersoids [17]. During the tensile test, the effect of dispersoids-dislocation interactions became more remarkable due to the increase of dislocation density [19]. It was reported that dispersoids can change the slip system by means of cross-slip at high temperature when the dislocations were trapped by dispersoids, making the homogenization of slip [20], explaining of much more uniformly distributed dimples in Alloy B. Besides, it was also proposed that the homogenization deformation can be highly promoted by converting the dislocation movement from the planar slip to a wavy slip mode through cross slip [21], which would also benefit for the higher ductility. Therefore, the formation of dispersoids was the likely reason for both higher strength and better ductility in Alloy B.

\section{Conclusions}

In the present work, the evolution of microstructure and elevated-temperature strength in 6xxx alloys containing various $\mathrm{Mn}$ was investigated during hot-rolling and postrolling annealing processes and the following conclusions can be drawn:

(1). After the pre-heat treatment before rolling $\left(400^{\circ} \mathrm{C} / 2 \mathrm{~h}\right)$, high volume of larger $\mathrm{Mg}_{2} \mathrm{Si}$ was precipitated in the base alloy free of $\mathrm{Mn}$ while a number of fine rod-like dispersoids were dominate precipitates with lower volume and smaller $\mathrm{Mg}_{2} \mathrm{Si}$ in Mn-containing alloy.

(2). During the hot rolling, the dispersoids was transfer from rod-like to the spherical and most of smaller $\mathrm{Mg}_{2} \mathrm{Si}$ has dissolved into matrix in Mn-containing alloy. However, high volume of fragmented larger $\mathrm{Mg}_{2} \mathrm{Si}$ was still remaining in base alloy free of $\mathrm{Mn}$.

(3). During the post-rolling annealing process at $500^{\circ} \mathrm{C}$, fully recrystallization was observed after $1-2 \mathrm{~h}$ in base alloy free of $\mathrm{Mn}$ while only partial recrystallization was observed in Mn-containing alloys, even after $8 \mathrm{~h}$.

(4). The elevated-temperature strength and microhardness at room temperature was firstly increase from as-rolled to $500^{\circ} \mathrm{C} / 1 \mathrm{~h}$ followed by a plateau or a gradually reduction in both alloys. However, they were always higher in Mn-containing alloy than the base alloy and the biggest difference was observed at as-rolled condition while the difference was becoming smaller with increasing post-rolling annealing time.

(5). Tensile fracture surface at $300^{\circ} \mathrm{C}$ was observed to be ductile with the presence of dimples under all the conditions of both experimental alloys, which is 
confirmed by the high total strain at failure $(\sim 0.35)$. However, the dimples were smaller and more uniformly distributed in Mn-containing alloy, leading to its higher ductility.

The authors would like to acknowledge the financial support of the Natural Sciences and Engineering Research Council of Canada (NSERC) and Rio Tinto Aluminum through the Research Chair in the Metallurgy of Aluminum Transformation at University of Quebec in Chicoutimi.

\section{Reference}

[1] J. G. Kaufman: Properties of aluminum alloys : tensile, creep, and fatigue data at high and low temperatures, ASM International ; Aluminum Association, Materials Park, Ohio; Washington, D.C., 1999.

[2] K. Liu and X. G. Chen, Mater. Des. 84, 340 (2015).

[3] K. Liu, H. Ma and X. G. Chen, J. Alloys Compd. 694, 354 (2017).

[4] L. Jin, K. Liu and X.-G. Chen, J. Mater. Eng. Perform. 29, 126 (2020).

[5] Z. Li, Z. Zhang and X. G. Chen, Mater. Sci. Eng., A 708, 383 (2017).

[6] L. Lodgaard and N. Ryum, Mater. Sci. Eng., A 283, 144 (2000).

[7] R. Hu, T. Ogura, H. Tezuka, T. Sato and Q. Liu, J. Mater. Sci. Technol. 26, 237 (2010).

[8] F. Hichem and G. Rebai, Appl. Phys. A 119, 285

(2015).

[9] C. Li, K. Liu and X. G. Chen, J. Mater. Sci. Technol. 39, 135 (2020).

[10] X. Qian, N. Parson and X. G. Chen, Mater. Sci. Eng., A 764, 138253 (2019).

[11] C. Li, K. Liu, N. Parson and X.-G. Chen. The effect of heat treatment on precipitation behavior of dispersoids in Al-Mg-Si Alloy In: M. W. a. M. Brochu, editor. Proceeding of 16th international Aluminum Alloys Conference (ICAA16). Mcgill University, Montreal, Canada: Candian Institute of Mining, Metallurgy \& Petroleum; 2018.

[12] Z. Li, Z. Zhang and X. G. Chen, Metall. Mater. Trans. A 49, 5799 (2018).

[13] J. D. Robson, T. Hill and N. Kamp, Mater. Sci. Forum 794-796, 697 (2014).

[14] S. Roy, S. S. D, S. Suwas, S. Kumar and K. Chattopadhyay, Mater. Sci. Eng., A 528, 8469 (2011).

[15] H. Jazaeri and F. J. Humphreys, Acta Mater. 52, 3251 (2004).

[16] E. Nes, N. Ryum and O. Hunderi, Acta Metall. 33, 11 (1985).

[17] S. Chen, K. Liu and X. G. Chen, J. Mater. Res. 34, 3071 (2019).

[18] A. R. Farkoosh, X. G. Chen and M. Pekguleryuz, Mater. Sci. Eng., A 627, 127 (2015).

[19] O. Sitdikov, E. Avtokratova, T. Sakai and K. Tsuzaki, Metall. Mater. Trans. A 44, 1087 (2013).

[20] S. W. Nam and D. H. Lee, Met. Mater. Int. 6, 13 (2000).

[21] K. C. Kim and S. W. Nam, Mater. Sci. Eng., A 244, 257 (1998). 